\title{
DETERMINANTS OF REVEALED COMPARATIVE ADVANTAGES: THE CASE OF CHEESE TRADE IN THE EUROPEAN UNION
}

\author{
J.M. BALOGH* and A. JÁMBOR \\ Department of Agricultural Economics and Rural Development, Corvinus University of Budapest, \\ H-1093 Budapest, Fővám tér 8. Hungary
}

(Received: 11 July 2015; accepted: 22 August 2015)

\begin{abstract}
Revealed comparative advantages are widely used by the global literature to analyse international trade flows, though agricultural trade is usually neglected in empirical works. Moreover, the determinants of revealed comparative advantages are scarcely investigated. This article analyses revealed comparative advantages in European Union's cheese trade from 1990 to 2013 and identifies its determinants by using panel data econometrics. Results suggest that GDP/capita, geographical indication, and EU membership are positively, while foreign direct investment (FDI) is negatively related to revealed comparative advantages.

Keywords: revealed comparative advantages, determinants, cheese trade, European Union
\end{abstract}

Since the seminal work of BALASSA (1965), a vast amount of literature is dedicated to the analyses of revealed comparative advantages of global trade. Despite the apparent importance of the topic, most studies have focused on industrial products, with agro-food sectors usually neglected in empirical works. Moreover, the determinants of revealed comparative advantages are also scarcely investigated in empirical works.

Therefore, the aim of the paper is to analyse the structure and determinants of EU cheese trade on global markets. By doing so, the paper adds to the literature by identifying the determinants of comparative advantages in the EU dairy sector. Such an approach, at least to our knowledge, is novelty in the literature. The paper is structured as follows. Section 1 presents an overview of the literature, followed by a demonstration of the methodology and hypotheses (section 2). Section 3 shows the results of the model runs, while the last section concludes.

\section{Literature review}

Bojnec (2001) and FerTő and HubBARd (2003) were among the first to analyse revealed comparative advantages in CEE agro-food sectors. FERTö (2008) analysed the evolution of agro-food trade patterns in Central European countries and found trade specialisation to be mixed. For particular product groups, greater variation was observed, with generally stable (unstable) patterns of variation for product groups with comparative disadvantage (advantage). BOJNEC and FERTŐ (2008) analysed the competitiveness of dairy trade in Croatia, Hungary, and Slovenia and concluded that these countries have faced serious difficulties in maintaining their competitive positions in the EU markets and called for a restructuring of the sector.

\footnotetext{
* To whom correspondence should be addressed.

Phone: +36-20-807 35 96; e-mail: jeremias.balogh@stud.uni-corvinus.hu
} 
QINETI and co-workers (2009) analysed the competitiveness and comparative advantage of Slovak and EU agro-food trade with Russia and Ukraine and found that comparative advantage had been lost for a number of product groups over time, though results for individual product groups varied significantly.

BOJNEC and FERTŐ (2009) searched for agro-food trade competitiveness of Central European and Balkan countries and showed that bulk primary raw agricultural commodities had higher and more stable relative trade advantages compared to consumer-ready foods, implying competitiveness shortcomings in food processing and in international food marketing. BOJNEC and FERTŐ (2012) investigated the impact of EU enlargement on agro-food export performance of New Member States (NMS) over 1999-2007 and found longer duration for exporting higher value-added specialized consumer-ready food and more competitive niche agro-food products. BOJNEC and FERTÖ (2014b) analysed the agro-food competitiveness of European countries and showed that most of the old EU15 member states experienced a greater number of agro-food products having a longer duration of revealed comparative export advantages than most of the new EU12 member states have.

JÁMBOR (2013) analysed the comparative advantages and specialisation of the Visegrad Countries agro-food trade and showed that comparative advantages decreased after accession in all countries, suggesting a weakening stability of competitive positions. TöRÖK and JÁMBOR (2013) analysed New Member States agro-food trade patterns and highlighted that almost all countries experienced a decrease in their comparative advantage after the accession, though it still remained at an acceptable level in most cases. BOJNEC and FERTő (2014a) analysed the export competitiveness of EU dairy products on the global market and found that competitiveness was generally higher in the case of processed milk products.

\section{Methods and hypotheses}

The various methods elaborated around the theory of revealed comparative advantage provide the basis for analysis. The original index of revealed comparative advantage was first published by BALASSA (1965), who defined the following:

$$
B_{i j}=\left(\frac{X_{i j}}{X_{i t}}\right) /\left(\frac{X_{n j}}{X_{n t}}\right)
$$

where $X$ means export, $i$ indicates a given country, $j$ is a given product, $t$ is a group of products, and $n$ is a group of countries. It follows that a revealed comparative advantage (or disadvantage) index of exports can be calculated by comparing a given country's export share of its total exports with the export share in total exports of a reference group of countries. If $\mathrm{B}>1$, a given country has a comparative advantage compared to the reference countries or, in contrast, a revealed comparative disadvantage if $\mathrm{B}<1$.

The Balassa-index is criticized because it neglects the different effects of agricultural policies and exhibits asymmetric values. Trade structure is distorted by different state interventions and trade limitations, while the asymmetric value of the B index reveals that it extends from one to infinity if a country enjoys a comparative advantage, but in the case of comparative disadvantage, it varies between zero and one, which overestimates a sector's relative weight. VOLLRATH suggested three different specifications of revealed comparative advantage in order to eliminate the disadvantages of the Balassa-index, the detailed description of which can be found in VOLLRath (1991). 
In order to treat the asymmetric value problem of the Balassa-index, DALum and coworkers (1998) transformed B index as follows, thereby creating the Revealed Symmetric Comparative Advantage (RSCA) index:

$$
R S C A=(B-1) /(B+1)
$$

The RSCA takes values between -1 and 1 , with values between 0 and 1 indicating a comparative export advantage and values between -1 and 0 a comparative export disadvantage. Since the RSCA distribution is symmetric around zero, a potential bias is avoided (DALUM et al., 1998).

Yu and co-workers $(2009,2010)$ adopted an alternative measure to assess the dynamics of comparative advantages - the Normalised Revealed Comparative Advantage (NRCA) index, defined as follows:

$$
N R C A_{\mathrm{ij}}=\frac{X_{i j}}{E_{i} E_{j} X_{i j}}-\frac{\left(E_{i} X_{i j}\right)\left(E_{j} X_{i j}\right)}{\left(E_{i} E_{j} X_{i j}\right)^{2}}
$$

where $X_{i j}$ represents actual exports and $\left(E_{i} X_{i j}\right)\left(E_{j} X_{i j}\right)$ stands for the comparative-averageneutral level in exports of commodity $j$ for country i. If NRCA $>0$, a country's comparative advantage on the world market is revealed. The distribution of NRCA values is symmetrical, ranging from $-1 / 4$ to $+1 / 4$ with 0 being the comparative-advantage-neutral point.

The paper employs EU cheese trade data for 1990-2013 and, in this context, the EU is defined as the member states of the EU27. Cheese trade is defined as intra-EU27 trade in SITC-1 revision, product code: 0240 cheese and curd. The reason for analysing only internal EU27 trade for cheese is that $80 \%$ of EU cheese export is sold on the internal market on average between 1990 and 2013.

Furthermore, the paper concentrates on the B index (and its transformation, the RSCA and NRCA index) as it excludes imports, which are more likely to be influenced by policy interventions. The phasing out of export subsidies is a further reason to choose a B-based index. Based on the theoretical and empirical research to date, the following hypotheses are tested here.

H1: Higher factor endowments increase comparative advantages.

The difference in factor endowments is usually measured by inequality in per capita GDP, in line with FALVEY and KIERZKOWSKI (1987). It seems reasonable that higher factor endowments of a country leads to higher comparative advantages based on the higher number of resources available (JÁMBOR, 2014). Factor endowments are proxied by the logarithm of per capita GDP (lnGDPPC), which is expected to be positively related to comparative advantages. Per capita GDP is measured in PPP in constant 2005 US dollars, where the data come from the World Bank World Development Indicators, WDI (2014) database.

H2: Capital investments are against comparative advantages.

As evident from JANG and HYUN (2012), the relationship between FDI and comparative advantages is ambiguous. However, as cheese production is strongly linked to a nation's culture and tradition, thus cheese producer companies are usually in national property. Therefore, here we assume that capital investment, proxied by Foreign Direct Investment (FDI), discourages comparative advantages. FDI data is coming from the FAOSTAT DATABASE (2014) and is measured in USD. 
H3: Geographical indication is positively related to comparative advantages.

The food quality policy of the European Union underlines the importance of the place of origin. Geographical indication guarantees that an agricultural product is produced under the highest food quality standards in a region. The PDO variable in our model is measured by the number of cheese PDO a member state has.

H4: EU accession is positively related to comparative advantages.

Previous studies (FERTÖ \& Soós, 2009; BoJNEC \& FERTÖ, 2012) show that the duration of trade in both manufacturing and agro-food products differs across European markets. For the majority of countries the duration of trade is greater in EU10/12 markets than in EU15 markets. It is evident that economic integration fosters agro-food trade, which will occur as new members become integrated. This hypothesis is tested by a dummy variable with a value of 1 if the reporter is an EU member and a 0 if not.

The paper applies the gravity equation approach to analyse the determinants of comparative advantages of EU cheese trade in 1990-2013. On the whole, we estimate the following regression model:

$$
R C A_{\mathrm{it}}=\alpha+\beta_{1} \ln G D P P C_{\mathrm{it}}+\beta_{2} \ln F D I_{\mathrm{it}}+\beta_{3} P D O_{\mathrm{it}}+\beta_{4} E U_{\mathrm{it}} u_{\mathrm{i}}+\varepsilon_{\mathrm{it}}
$$

Table 1 provides an overview of the description of variables and related hypotheses.

Table 1. Description of independent variables

\begin{tabular}{llll}
\hline Variable & Description & Data source & Exp. sign \\
\hline lnGDPPC & GDP per capita (in constant 2005 USD) & World Bank WDI & + \\
InFDI & Foreign Direct Investment in agriculture (in USD) & FAOSTAT & - \\
PDO & $\begin{array}{l}\text { Number of cheese products with PDO by year and by } \\
\text { country }\end{array}$ & EUROSTAT DOOR database & + \\
EU & $\begin{array}{l}\text { EU accession dummy (1 if a country is the member of } \\
\text { the EU in a given year and 0 otherwise) }\end{array}$ & - & + \\
& & & \\
\hline
\end{tabular}

Many static and dynamic panel data techniques are available including pooled OLS, fixed effects (FE), random effects (RE), feasible generalised least squares (FGLS), and the GMM-SYS method, based on the recent studies (LeItAo, 2012; JÁmbor, 2014; Fertö \& JÁMBOR, 2015), the FGLS method provided the best results for our sample. In estimating the determinants of comparative advantages, the panel-data linear feasible generalized least squares (xtgls) estimation technique is applied to equation (4) with time series autocorrelation calculation (tscorr) and heteroscedastic error structure (panels heteroscedastic) option in order to ensure the robustness of the results and the control for heteroscedasticity.

\section{Results and discussion}

Before estimating panel regression models, the applied variables were pre-tested for heteroscedasticity and serial correlation. The modified Wald test confirmed the presence of heteroscedasticity $(\mathrm{P}=0.0000)$. Wooldridge test for autocorrelation (WoOLDRIDGE, 2002; 
DRUKKER, 2003) rejects the hypothesis of no serial correlation $(\mathrm{P}=0.0000)$. In other words, serial correlation also occurs in our panel data.

The estimated results show significant coefficients and expected signs in all cases. In the first model specification, every estimated coefficient is significant at $1 \%$ and $5 \%$ levels. The second model shows more significant results at $1 \%$, while the results of the third model are also mostly significant (Table 2).

Table 2. Regression results of European intra cheese industry

\begin{tabular}{lccc}
\hline \multirow{2}{*}{ Variables } & $(1)$ & $(2)$ & $(3)$ \\
\hline $\ln$ GDPpc & RCA & RSCA & NRCA \\
\cline { 2 - 2 } & $0.559^{* *}$ & $0.200^{* *}$ & $2.00 \mathrm{e}-05^{* *}$ \\
$\operatorname{lnFDI}$ & $(0.0685)$ & $(0.0265)$ & $(3.00 \mathrm{e}-06)$ \\
& $-0.283^{* *}$ & $-0.0674^{* *}$ & $-9.83 \mathrm{e}-06^{* *}$ \\
PDO & $(0.0281)$ & $(0.00866)$ & $(1.33 \mathrm{e}-06)$ \\
& $0.0110^{*}$ & $0.00876^{* *}$ & $1.04 \mathrm{e}-06^{*}$ \\
EU & $(0.00491)$ & $(0.00122)$ & $(4.97 \mathrm{e}-07)$ \\
& $0.561^{* *}$ & $0.257^{* *}$ & $1.09 \mathrm{e}-05^{*}$ \\
Constant & $(0.110)$ & $(0.0455)$ & $(4.79 \mathrm{e}-06)$ \\
& $1.417^{*}$ & $-0.975^{* *}$ & $-1.78 \mathrm{e}-06$ \\
Observations & $(0.624)$ & $(0.222)$ & $(3.72 \mathrm{e}-05)$ \\
Number of countries & 528 & 528 & 528 \\
\hline
\end{tabular}

Note: Standard errors in parentheses, significance levels are **: $\mathrm{P}<0.01 ; *: \mathrm{P}<0.05$

Source: calculations are based on Word Bank WITS database

Regarding the regression coefficients, GDP per capita, PDO, FDI, and EU accession significantly determine revealed comparative advantages. Factor endowments (GDP per capita) are found to be positively related to comparative advantages, implying that the abundance of resources influence competitiveness in a positive way. In other words, higher factor endowments increase comparative advantages, meaning that countries with more land, labour, and capital have better chances to become competitive. As concerns foreign direct investment, we found a negative relationship between foreign capital and competitiveness in the European cheese industry, showing that FDI and comparative advantages do not necessarily go together. However, PDO and comparative advantages were found to be positively related, showing that protected geographical indication implies an advantage in EU internal market. This is especially important given that more than 200 cheese products have a PDO in the EU, according to the EUROSTAT DOOR DATABASE (2015). Finally, EU membership representing the common market also plays a positive role in European cheese export competitiveness, implying that EU members as part of an economic integration have generally higher comparative advantages in the EU cheese market than third countries. All the three models provided consistent and significant results.

We are aware that these arguments should be treated with care, as the methodology has a number of limitations. First, trade data are not fully reliable for a number of reasons. Trade 
values do not necessarily sum up to the total trade value for a given country dataset, countries do not necessarily report their trade values for each and every year, trade data differ by the selection of classification and so on, imports reported by one country do not coincide with exports reported by its trading partner. Second, Balassa-based indices are sensitive to zero values (see Equation 1, for instance). Third, selection of a different trading partner might alter our results. However, our findings are consistent with the majority of the competitiveness literature.

\section{Conclusions}

The article analysed the determinants of revealed comparative advantages of EU cheese trade from 1990 to 2013 and identified four factors significantly determining a country's competitive positions in this market. By applying panel-data linear feasible generalized least squares (xtgls) estimation models, we found that factor endowments, geographical indication and EU membership positively and significantly determined revealed comparative advantages in the European cheese market, while FDI negatively affected competitive positions in EU cheese trade. Although our model has various limitations, results are consistent with the majority of the existent literature. Future research might want to search for other determinants or repeat calculations to other sectors/countries to increase the validity of our results.

The authors gratefully acknowledge two anonymous referees for their helpful comments and suggestions on earlier drafts of this manuscript. The research for this paper was supported by the Hungarian Scientific Research Fund Project No. 112394, '10 years of Accession: Lessons from the agro-food sector of the New Member States' and by the János Bolyai Research Scholarship of the Hungarian Academy of Sciences.

\section{References}

BALAssa, B. (1965): Trade liberalization and revealed comparative advantage. Manch. Sch. Econ. Soc., 33, $99-123$. BoJNEC, Š. (2001): Trade and revealed comparative advantage measures: regional and Central and East European agricultural trade. Eastern Eur. Econ., 39, 72-98.

Bojnec, Š. \& FERTÖ, I. (2008): Dairy trade competitiveness: crucial role of processed products. Milchwissenschaft, 63, 434-438.

Bojnec, Š. \& FerTő, I. (2009): Agro-food trade competitiveness of Central European and Balkan countries. Food Policy, 34, 417-425.

Bojnec, Š. \& Fertö, I. (2012): Does EU enlargement increase agro-food export duration? World Econ., 35, $609-631$.

BoJnec, Š. \& FERTö, I. (2014a): Export competitiveness of dairy products on global markets: The case of the European Union countries. J. Dairy Sci., 97, 6151-6163.

BoJnec, Š. \& FerTö, I. (2014b): Agri-food export competitiveness in European Union countries. JCMS-J. Common Mark. S., 53, 476-492

Dalum, B., Laursen, K. \& Villumsen, G. (1998): Structural change in OECD export specialisation patterns: Despecialisation and 'stickiness'. Int. Rev. Appl. Econ., 12, 423-443.

DrukKer, D.M. (2003): Testing for serial correlation in linear panel-data models. Stata J., 3, 1-10.

EUROSTAT DOOR DATABASE (2015): Available at http://ec.europa.eu/agriculture/quality/door (last accessed 5 March 2015).

Falvey R. \& KierzKowski, H. (1987): Product quality, intra-industry trade and (im)perfect competition. -in: Kierzkowski, H. (Ed.) Protection and competition in international trade. Blackwell, Oxford, pp. 143-161.

FAOSTAT Database (2014): Rome: Food and Agriculture Organization of the United Nations, Available at http:// faostat.fao.org/ (last accessed 3 May 2015)

FerTö, I. (2008): The evolution of agri-food trade patterns in Central European countries. Post-Communist Econ., 20, 1-10.

Acta Alimentaria 46, 2017 
Fertö, I. \& Hubbard, L.J. (2003): Revealed comparative advantage and competitiveness in Hungarian agri-food sectors. World Econ., 26, 247-259.

Fertö, I. \& JÁmbor, A. (2015): Drivers of vertical intra-industry trade: the case of the Hungarian agri-food sector. Agr. Econ., 46, 1-11.

FERTÖ, I. \& Soós, K.A. (2009): Treating trade statistics inaccuracies: the case of intra-industry trade. Appl. Econ. Lett., 16, 1861-1866.

JANG, Y.J. \& HyUn, H.-J. (2012): Comparative advantage, outward foreign direct investment and average industry productivity: Theory and evidence. KIEP Research Paper No. Working Paper-12-01

JÁmBor, A. (2013): Comparative advantages and specialisation of the Visegrad countries agri-food trade. Acta Oecon. Inform., 16, 22-34.

JÁmBOR, A. (2014): Country-specific determinants of horizontal and vertical intra-industry agri-food trade: The case of the EU New Member States J. Agr. Econ., 65, 663-682.

Leitao, N.C. (2012): Economic growth and intra-industry trade. AJER - Asian J. Empirical Res., 2, 3-83.

Qineti, A., Rajcaniova, M. \& Matejkova, E. (2009): The competitiveness and comparative advantage of the Slovak and the EU agri-food trade with Russia and Ukraine. Agr. Econ. - Czech, 55, 375-383.

Töröк, Á. \& JÁmBor, A. (2013): Agri-food trade of the New Member States since the EU accession. Agr. Econ.Czech, 59, 101-112.

Vollrath, T.L. (1991): A theoretical evaluation of alternative trade intensity measures of revealed comparative advantage. Weltwirtsch. Arch., 130, 263-279.

Wooldridge, J.M. (2002): Econometric analysis of cross section and panel data. Cambridge, Massachusetts, The MIT Press, 176 pages.

World BANK (2014): World Integrated Trade Solution (WITS) database, Available at https://wits.worldbank.org/ (last accessed 8 February 2015)

World Development Indicators, WDI (2014): World Bank database, Available at http://data.worldbank.org/datacatalog/world-development-indicators (last accessed 22 November 2014)

Yu, R., Cai, J. \& Leung, P.S. (2009): The normalized revealed comparative advantage index. Ann. Regional Sci., 43, 267-282.

Yu, R., Cai, J., Loke, M.K. \& Leung, P.S. (2010): Assessing the comparative advantage of Hawaii's agricultural exports to the US mainland market. Ann. Regional Sci., 45, 473-485. 